\title{
Cardiomyopathy-Associated Gene 1-Sensitive PKC-Dependent Connexin 43 Expression and Phosphorylation in Left Ventricular Noncompaction Cardiomyopathy
}

\author{
Yuanyuan Xie Shenghua Liu Shengshou Hu Yingjie Wei \\ State Key Laboratory of Cardiovascular Disease, National Center for Cardiovascular Disease and Fuwai \\ Hospital, Chinese Academy of Medical Sciences, Peking Union Medical College, Beijing, PR China
}

\section{Key Words}

Left ventricular noncompaction cardiomyopathy (LVNC) • Cardiomyopathy-associated gene 1 (CMYA1) • Connexin $43($ Cx43) • PKC signaling pathway

\begin{abstract}
Background/Aims: Cardiomyopathy-associated gene 1 (CMYA1) plays an important role in embryonic cardiac development, postnatal cardiac remodeling and myocardial injury repair. Abnormal CMYA1 expression may be involved in cardiac dysplasia and primary cardiomyopathy. Our study aims to establish the relationship between CMYA1 and Left ventricular noncompaction cardiomyopathy (LVNC) pathogenesis. Methods: We explored the effects of CMYA1 on connexins (Cx), which contribute to gap junction intercellular communication (GJIC), and the underlying signaling pathway in human normal tissues, LVNC myocardial tissues and HL1 cells by means of western blotting, RT-qPCR, immunohistochemistry, immunofluorescence, co-immunoprecipitation and scrape loading-dye transfer. Results: CMYA1 expression was inversely associated with $\mathrm{C} \times 43$ and $\mathrm{C} \times 40$ expression, as determined by gap junction PCR array analysis. An increased expression and disordered distribution of CMYA1 at the intercalated discs in LVNC myocardial tissue was also observed. CMYA1 and Cx43 are co-expressed and interact in myocardial cells. CMYA1 expression was positively correlated with p-Cx43 (S368) via the Protein kinase C (PKC) signaling pathway in myocardial tissue and HL1 cells. The diffusion distance of Lucifer Yellow in the HL1 cells in which CMYA1 was over-expressed or knocked down was significantly less or more than that of the control group, respectively. Conclusion: Abnormal CMYA1 expression affects the expression and phosphorylation of Cx43 through the PKC signaling pathway, which is involved in the regulation of GJIC. CMYA1 participates in the molecular mechanism of LVNC pathogenesis.




\section{Introduction}

Left ventricular noncompaction cardiomyopathy (LVNC) is a primary hereditary cardiomyopathy potentially associated with abnormal embryonic development of the heart [1] characterized by numerous prominent trabeculations and deep intertrabecular recesses in the left ventricle. The most common clinical presentations of LVNC are congestive heart failure, cardiac arrhythmia and thromboembolism [2]. Mutations in sarcomere protein, Z-disc, cytoskeletal and mitochondrial genes have been found in LVNC cases [3-8], which only explains a small portion of the causes of LVNC. Therefore, novel pathogenic LVNC genes must be identified and verified.

CMYA1, also named XIRP1, is a member of the cardiomyopathy-associated gene family (CMYA) which was originally discovered by Chinese scholars analyzing differentially expressed genes in chick embryonic heart development [9]. CMYA1 is located on chromosome 3p22.2 and encodes a protein called Xin, which means "heart" in Chinese [10]. Incubation of chick embryos with cCMYA1 antisense oligonucleotides results in abnormal cardiac morphogenesis and altered cardiac looping. The myocardial tissue of affected hearts becomes thickened and tends to form multiple invaginations into the heart cavity. cCMYA1 plays a key role in cardiac morphogenesis and development [11]. CMYA1 knockout during mouse embryonic development demonstrated that CMYA1 also plays a role in mammalian myocardial wall development and morphogenesis [12]. CMYA1 has been shown to be highly expressed in intercalated discs (ICDs) in mouse and pig hearts [12-15], suggesting its potential association with the cyclization process of cardiac development and myocardial contractility [10]. Novel mutations in the conserved region of the CMYA1 gene in patients with LVNC have recently been identified (not published in our preliminary work), and CMYA1 mutations reportedly may lead to the mislocalization of CMYA1 and other ICD components to the ICDs and, consequently, the noncompaction phenotype [16].

ICDs are part of the cardiac muscle sarcolemma, as they contain gap junctions (GJs) and desmosomes [17]. GJs are important determinants of cardiac conduction, and evidence has recently emerged that altered distribution of these junctions and altered expression of their constituent connexins $(\mathrm{Cx}$ ) may lead to abnormal coupling between cardiomyocytes, likely contributing to myocardial diseases [18]. Twenty-one connexins have been identified in humans. Cx43 is the major subtype of ventricular myocardium [19]. Disorganization of GJ distribution and down-regulation of $\mathrm{Cx} 43$ are typical features of myocardial remodeling and may play an important role in the development of arrhythmogenic substrates in human cardiomyopathies [18].

The purpose of this study is to clarify the effects of CMYA1 on the gap junction intercellular communication (GJIC) of cardiomyocytes and the underlying signaling pathway.

\section{Materials and Methods}

\section{Cell culture and treatment}

HL1 cells were cultured in Dulbecco's Modified Eagle's Medium supplemented with 10\% fetal bovine serum (GIBCO) at $37^{\circ} \mathrm{C}$ and 5\% CO2 in a humidified incubator, and the medium was changed every two days. Cells were serum-starved for $24 \mathrm{~h}$ once they reached $70 \%$ confluency. They were then either infected with lentiviral particles or transfected with shRNA-CMYA1 plasmids. After treatment with the lentiviral particles or plasmids for 24,48 , or $72 \mathrm{~h}$, the HL1 cells were harvested for the experiments (co-immunoprecipitation, western blotting, RT-qPCR, immunocytochemistry, and scrape loading-dye transfer). The HL1 cells were cultured in serum-free medium for $12 \mathrm{~h}$ before being exposed to the protein kinase C (PKC) inhibitor GF109203X or the PKC activator phorbol 12-myristate 13 acetate (PMA).

Tissue samples

Myocardial samples were taken from the LVs of 12 terminal cardiomyopathy patients exhibiting abnormal trabeculation morphology from our heart transplantation program. Non-cardiomyopathy 


\section{Cellular Physiology Cell Physiol Biochem 2017;44:828-842 \begin{tabular}{l|l|l} 
and Biochemistry 10.1159/000485348 & $\begin{array}{l}\text { C) } 2017 \text { The Author(s). Published by S. Karger AG, Basel } \\
\text { www.karger.com/cpb }\end{array}$ \\
\hline
\end{tabular} \\ Xie et al.: Effects of CMYA1 On Cx43 via the PKC Signaling Pathway}

control hearts were harvested from donors with no history of heart disease who died in accidents. All the participants provided written informed consent for this investigation, which was approved by the Institutional Ethical Review Board of Fuwai Hospital. The investigation also conforms to the principles outlined in the Declaration of Helsinki.

\section{Western blot analysis}

Total proteins from the tissues and HL1 cells were analyzed as previously described [20]. Briefly, the frozen tissues and cultured cells were lysed and centrifuged at $15,000 \mathrm{~g}$ at $4^{\circ} \mathrm{C}$ for $10 \mathrm{~min}$. Then, the supernatants were collected and assayed by the BCA protein assay method. Subsequently, the protein samples were subjected to SDS-PAGE (4-12\% gradient) and transferred to PVDF membranes. After being blocked with $5 \%$ skim milk and incubated with antibodies, the proteins were visualized by enhanced chemiluminescence (ECL) and detected using the Fluor Chem M Multi Fluor system (Cell Biosciences).

The following primary antibodies were used: mouse anti-CMYA1 (Santa Cruz Biotechnology), rabbit anti-Cx43 (Cell Signaling Technology), goat anti-Cx40 (Santa Cruz Biotechnology), rabbit anti-PhosphoCx43 (Ser368) (Santa Cruz Biotechnology), and rabbit anti-GAPDH (Cell Signaling Technology). Horseradish peroxidase-linked secondary antibodies (Beyotime Biotechnology) were also used.

\section{Real-time quantitative PCR analysis}

Total RNA was extracted from the myocardial tissues and cultured cells using TRIzol reagent (Invitrogen) according to a previously published method [21]. Total RNA was subjected to reverse transcription using the Hieff First Strand cDNA Synthesis Kit (Yeasen, Shanghai). Real-time quantitative PCR (RT-qPCR) experiments were performed using the 7500 Sequence Detection System (Applied Biosystems). The RT-qPCR procedure consisted of an initial denaturation step at $95^{\circ} \mathrm{C}$ for $5 \mathrm{~min}$, followed by 40 cycles of $95^{\circ} \mathrm{C}$ for $10 \mathrm{~s}$ and $60^{\circ} \mathrm{C}$ for $30 \mathrm{~s}$. Primer sequences of the investigated genes were as follows: 5'-CAGCAGCATCTGTTTGAGAC-3' (sense) and 5'-CCCTTTAGCTCATCCCTCTG-3' (antisense) for CMYA1; 5'-TCTGCTATGACAAGTCCTTCC-3' (sense) and 5'-GCTTCTCTTCCTTTCTCATCAC-3' (antisense) for Cx43; 5'-CATCTCCCACATTCGCTACTG-3' (sense) and 5'-CAATCCTTCCATTCCCTTCCT-3' (antisense) for Cx40; 5'-GGTCGGAGTCAACGGATTTG-3' (sense) and 5'ATGAGCCCCAGCCTTCTCCAT-3' (antisense) for GAPDH.

\section{Plasmid construction}

The CMYA1 coding region (NM_001198621) was cloned into the plent6v5 expression vector to obtain an expression construct with amino-terminal EGFP and FLAG tags. The shRNA-CMYA1 plasmid was constructed by inserting a short hairpin double-stranded oligonucleotide targeting CMYA1 (5'-CCGGAGTGCATGCGCTGGATCTTTGCTCGAGCAAAGATCCAGCGCATGCACTTTTTTTG- 3') into the pLKO.1 vector (Addgene). Human Cx43 DNA was amplified from genomic DNA and subcloned into the pDsRed1-N1 vector (with DsRed1 and Myc tags) (Bioworld Technology) [22]. The authenticity of all the sequences was verified by Sanger sequencing.

\section{Gene expression profiling of gap junctions}

A Qiagen Gap Junction PCR Array was used to profile the expression of 84 important gap junctionrelated genes. Total RNA was extracted using an RNeasy Mini kit. According to the manufacturer's instructions, RNA was digested using RNase-free DNase. RNA integrity was confirmed using a NanoDrop 2000 spectrophotometer (Thermo Fisher Scientific) and 1\% agarose gel electrophoresis. Quantification of human gap junction gene expression levels was determined using an RT2 First Strand kit and RT2 SYBR Green/ROX qPCR Master Mix with a 7500 Sequence Detection System (Applied Biosystems). Target gene expression levels were calculated according to the manufacturer's protocol using the Qiagen RT2 Profiler PCR Array. The relative expression of genes was determined using the comparative cycle threshold $(\Delta \Delta \mathrm{Ct})$ method.

\section{Immunohistochemistry and immunofluorescence}

HL1 cells were cultured on glass cover slips coated with poly-L-lysine. LV myocardial samples were fixed in 10\% neutral buffered formalin. Dehydration was accomplished using alcohol and xylene gradients, followed by paraffin embedding. Sections $(4 \mu \mathrm{m})$ were fixed for $10 \mathrm{~min}$ in $4 \%$ paraformaldehyde, permeabilized with $0.2 \%$ Triton X-100 for 5 min and blocked with $0.05 \% \mathrm{H}_{2} \mathrm{O}_{2}$. They were then incubated 


\section{Cellular Physiology Cell Physiol Biochem 2017;44:828-842

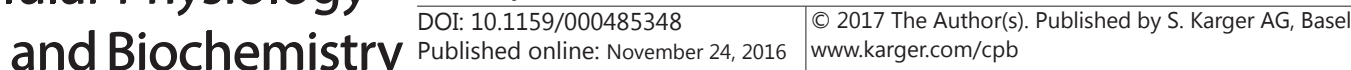 \\ Xie et al.: Effects of CMYA1 On Cx43 via the PKC Signaling Pathway}

with primary antibodies for $1 \mathrm{~h}$ at room temperature, washed with PBS for $10 \mathrm{~min}$, incubated with an IgGperoxidase conjugated secondary antibody for $1 \mathrm{~h}$ and washed with PBS for $10 \mathrm{~min}$. All the slides were stained with hematoxylin, dehydrated, and mounted. The immunofluorescence procedure was similar to that described above, except that blocking was achieved with 5\% BSA. Mounting and counterstaining were performed with DAPI. The immunohistochemistry images were acquired using a Leica DM750 microscope (magnification $630 \times$ in cells and $400 \times$ in tissues), and the immunofluorescence images were acquired using a Leica SP8 microscope (magnification 630x). The following antibodies were used: mouse anti-CMYA1 (Santa Cruz Biotechnology), rabbit anti-Cx43 (Cell Signaling Technology), goat anti-Cx40 (Santa Cruz Biotechnology), HRP-conjugated goat anti-rabbit (ZSGB-BIO), HRP-conjugated goat anti-mouse (ZSGB-BIO), Alexa 488-conjugated goat anti-mouse (Beyotime Biotechnology) and Alexa 647-conjugated goat antirabbit (Beyotime Biotechnology).

\section{Co-immunoprecipitation}

Protein G PLUS-Agarose (Santa Cruz Biotechnology) was washed with 1\% bovine serum albumin (BSA) and 10\% SDS in PBS. The agarose beads were then washed three times with PBS and 1\% BSA to remove the SDS. The HL1 cell lysates were incubated with $2 \mu \mathrm{g}$ of an anti-FLAG antibody or an anti-Myc antibody (Beyotime Biotechnology) overnight at $4^{\circ} \mathrm{C}$, followed by the addition of protein G PLUS-Agarose (Santa Cruz) overnight at $4^{\circ} \mathrm{C}$. The beads were washed three times with cold PBS. After $5 \%$ loading buffer (Beyotime Biotechnology) was added, the samples were boiled for $5 \mathrm{~min}$. The precipitates were subjected to immunoblotting with an anti-FLAG antibody or an anti-Myc antibody (Beyotime Biotechnology).

\section{GJIC bioassay}

HL1 cells were cultured in 6-well plates and treated with either GF109203X or PMA. The cells were scratched with a scalpel when they reached $90 \%$ confluency and then incubated with a gap junctionpermeable Lucifer yellow $\left(1 \mathrm{mg} / \mathrm{ml}\right.$ ) dye solution for $5 \mathrm{~min}$ at $37^{\circ} \mathrm{C}$. The cells were then washed three times with Hank's balanced salt solution (HBSS) and fixed in a 4\% paraformaldehyde solution for 10 min. The samples were imaged using a Leica DMI-4000B microscope. In three independent experiments, five fields of view per cell line were imaged, and each field of view was assessed at three places along the scratch for a total of 45 individual measurements for each cell line. The Lucifer yellow dye travel distance was quantified using ImageJ software.

\section{Statistical analysis}

All data are presented as the means \pm standard deviations. SPSS software 22.0 (IBM Analytics) was used for all statistical analyses. Differences between two groups were compared using ANOVA. In all the analyses, ${ }^{*} \mathrm{p}$ $<0.05$ and ${ }^{* *} \mathrm{p}<0.01$ were considered statistically significant.

\section{Results}

Analysis of the gap junction-related gene expression profiles in heart tissues and HL1 cells

Gene expression in gap junctions isolated from the myocardial samples and HL1 cells was examined using a PCR array employing
Table 1. List of genes down-regulated or up-regulated greater than 2-fold, as determined by PCR array analysis, in LVNC compared to expression in normal hearts

\begin{tabular}{|c|c|c|c|}
\hline GenBank & Symbol & Description & $\begin{array}{r}\text { Fold } \\
\text { change }\end{array}$ \\
\hline NM_000856 & GUCY1A3 & Guanylate cyclase 1 , soluble, alpha 3 & 0.27 \\
\hline NM_000165 & GJA1 & Gap junction protein, alpha $1,43 \mathrm{kDa}$ & 0.46 \\
\hline NM_005343 & HRAS & $\begin{array}{l}\text { V-Ha-ras Harvey rat sarcoma viral oncogene } \\
\text { homolog }\end{array}$ & 11.08 \\
\hline NM_000621 & HTR2A & 5-hydroxytryptamine (serotonin) receptor $2 \mathrm{~A}$ & 7.57 \\
\hline NM_032704 & TUBA1C & Tubulin, alpha $1 \mathrm{c}$ & 6.49 \\
\hline NM_005417 & SRC & $\begin{array}{l}\text { V-src sarcoma (Schmidt-Ruppin A-2) viral oncogene } \\
\text { homolog (avian) }\end{array}$ & 6.01 \\
\hline NM_002737 & PRKCA & Protein kinase $\mathrm{C}$, alpha & 3.37 \\
\hline NM_020040 & TUBB7P & Tubulin, beta polypeptide 4 , member $\mathrm{Q}$, pseudogene & 3.14 \\
\hline NM_002514 & NOV & Nephroblastoma over-expressed gene & 2.76 \\
\hline NM_002524 & NRAS & Neuroblastoma RAS viral (v-ras) oncogene homolog & 2.67 \\
\hline NM_002739 & PRKCG & Protein kinase $\mathrm{C}$, gamma & 2.14 \\
\hline
\end{tabular}




\section{Cellular Physiology and Biochemistry}

Cell Physiol Biochem 2017;44:828-842

\begin{tabular}{|l|l|l}
\hline DOI: $10.1159 / 000485348$ & C 2017 The Author(s). Published by S. Karger AG, Basel
\end{tabular}

Published online: November 24, 2016 www.karger.com/cpb

Xie et al.: Effects of CMYA1 On Cx43 via the PKC Signaling Pathway
84 genes relevant to gap junctions. We confined our analysis results to genes with a differential expression of at least 2 -fold. We compared the gene expression levels of human gap junction genes of cardiomyopathic tissues and normal control heart tissues; the 9 up-regulated genes were HRAS, NRAS, HTR2A, NOV, PRKCA, PRKCG, SRC, TUBA1C and TUBB7P, and the 2 down-regulated genes were $\mathrm{Cx} 43$ and GUCY1A3 (Fig. 1A, Table 1). We identified the altered expression of 12 genes, of which 6 were transcriptionally down-regulated and 6 were up-regulated (Fig. 1B, Table 2 ), in HL1 cells that overexpressed CMYA1. The upregulated genes included GJC2, GRB2, NOV, PRKG2, GUCY1A3 and PLCB2, and the down-regulated genes included GJA1, GJA5, GJC3, TJP1, PRKACA and ADRB2. Eleven genes were differentially expressed in HL1 cells in which CMYA1 was knocked down (Fig. 1C, Table 3). The up-regulated genes included GJA1 (Cx43), GJA5 (Cx40), GJA3, TJP1, GJA8, GJC2, GRB2, MAPK3, MAPK7 and PRKCG, whereas the only down-regulated gene was ADCY3. From the integrated analysis of twogroup data, three genes (GJA1, GJA5, and TJP1) showed opposite regulation trends in CMYA1 up-regulated or CMYA1 down-regulated HL1 cells. The gene functions were annotated. Two genes, Cx43 and Cx40, were determined to be connexins associated with the gap junction, and TJP1 is a connexin-interacting protein.
Table 2. List of genes down-regulated or up-regulated greater than 2-fold, as determined by PCR array analysis, in plent6v5-CMYA1transfected HL1 cells compared to expression in the control cells.

\begin{tabular}{|c|c|c|c|}
\hline GenBank & Symbol & Description & $\begin{array}{c}\text { Fold } \\
\text { change }\end{array}$ \\
\hline NM_175610 & TJP1 & Tight junction protein 1 (zona occludens 1 ) & 0.19 \\
\hline NM_000165 & GJA1 & Gap junction protein, alpha $1,43 \mathrm{kDa}$ & 0.24 \\
\hline NM_002730 & PRKACA & Protein kinase, cAMP-dependent, catalytic, alpha & 0.31 \\
\hline NM_181703 & GJA5 & Gap junction protein, alpha 5, $40 \mathrm{kDa}$ & 0.39 \\
\hline NM_020660 & GJD2 & Gap junction protein, delta 2, $36 \mathrm{kDa}$ & 0.39 \\
\hline NM_000024 & ADRB2 & Adrenergic, beta-2-, receptor, surface & 0.46 \\
\hline NM_000857 & GUCY1B3 & Guanylate cyclase 1 , soluble, beta 3 & 3.39 \\
\hline NM_000838 & GRM1 & Glutamate receptor, metabotropic 1 & 3.01 \\
\hline NM_006259 & PRKG2 & Protein kinase, cGMP-dependent, type II & 2.85 \\
\hline NM_002514 & NOV & Nephroblastoma over-expressed gene & 2.67 \\
\hline NM_004573 & PLCB2 & Phospholipase C, beta 2 & 2.57 \\
\hline NM_020435 & GJC2 & Gap junction protein, gamma 2, $47 \mathrm{kDa}$ & 2.46 \\
\hline
\end{tabular}

Table 3. List of genes down-regulated or up-regulated greater than 2-fold, as determined by PCR array analysis, in shRNA-CMYA1transfected HL1 cells compared to expression in the control cells.

\begin{tabular}{|c|c|c|c|}
\hline GenBank & Symbol & Description & $\begin{array}{c}\text { Fold } \\
\text { change }\end{array}$ \\
\hline NM_004036 & ADCY3 & Adenylate cyclase 3 & 0.09 \\
\hline NM_005267 & GJA8 & Gap junction protein, alpha $8,50 \mathrm{kDa}$ & 5.44 \\
\hline NM_002739 & PRKCG & Protein kinase $\mathrm{C}$, gamma & 4.75 \\
\hline NM_021954 & GJA3 & Gap junction protein, alpha $3,46 \mathrm{kDa}$ & 3.99 \\
\hline NM_002749 & MAPK7 & Mitogen-activated protein kinase 7 & 3.92 \\
\hline NM_080604 & TJAP1 & Tight junction associated protein 1 (peripheral) & 3.34 \\
\hline NM_020435 & GJC2 & Gap junction protein, gamma 2, $47 \mathrm{kDa}$ & 3.31 \\
\hline NM_000165 & GJA1 & Gap junction protein, alpha 1, $43 \mathrm{kDa}$ & 3.22 \\
\hline NM_181703 & GJA5 & Gap junction protein, alpha 5, $40 \mathrm{kDa}$ & 3.03 \\
\hline NM_002746 & MAPK3 & Mitogen-activated protein kinase 3 & 2.92 \\
\hline NM_002086 & GRB2 & Growth factor receptor-bound protein 2 & 2.91 \\
\hline
\end{tabular}




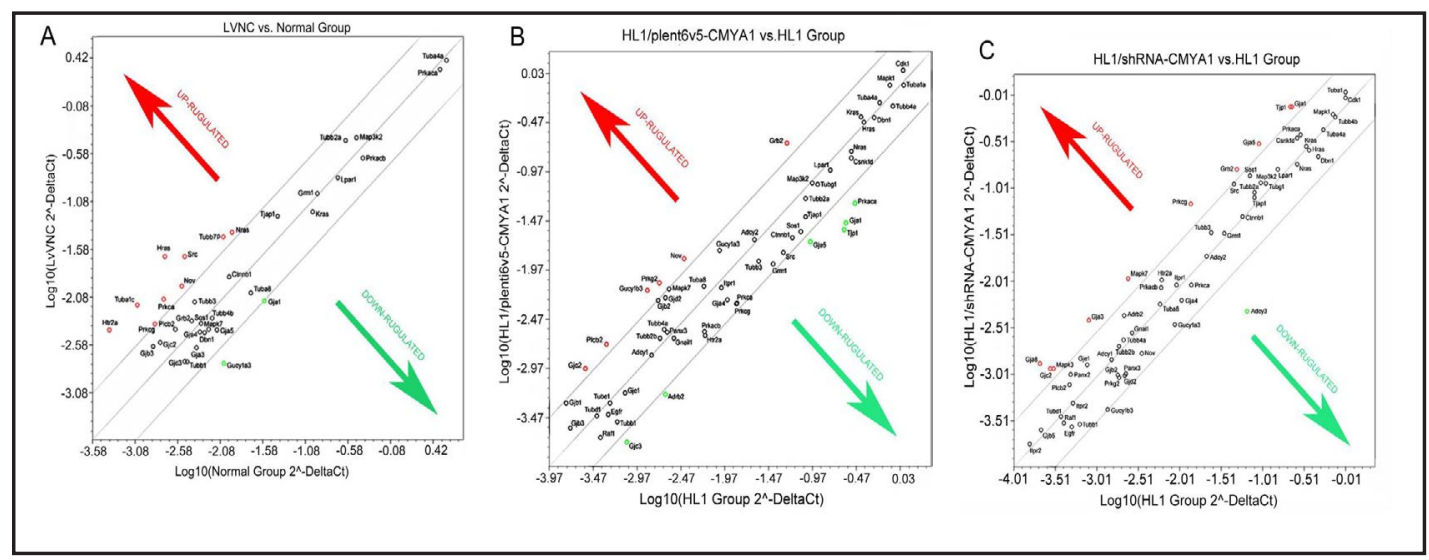

Fig. 1. Analysis of the gap junction PCR array. Scatter plot of PCR array analysis: 84 genes were observed to be up-regulated or down-regulated in the human hearts with LVNC (A) compared to expression in the normal hearts and in plent6v5-CMYA1-transfected (B) or shRNA-CMYA1-transfected (C) HL1 cells compared to expression in the control cells. The gray lines indicate the desired threshold of a 2.0 -fold change in gene expression.

Fig. 2. Expression of CMYA1, Cx43 and Cx40 in human cardiac tissues. (A) Representative images of CMYA1, Cx43 and $\mathrm{Cx} 40$ protein expression in human hearts with LVNC and normal hearts, as determined by immunohisto chem is try. The slide was counterstained with hematoxy-

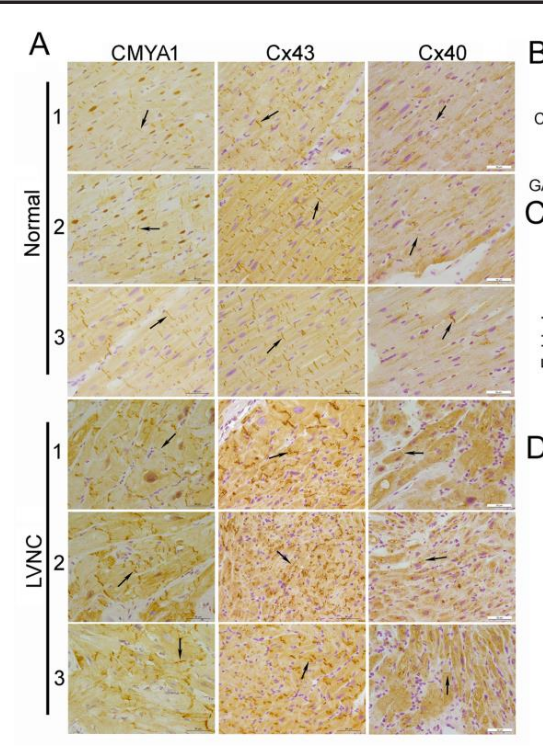
lin. Brown spots represent the CMYA1-, Cx43- and Cx40-positive cells that are localized at the ICDs of human hearts (arrows) (magnification 400×). (B) Western blot analysis showing increased protein levels of CMYA1 and reduced protein levels of $\mathrm{Cx} 43$ and $\mathrm{Cx} 40$ in the human hearts with LVNC. (C) Bar graphs showing the relative levels of the CMYA1, $\mathrm{Cx} 43$ and $\mathrm{Cx} 40$ proteins ( $\mathrm{n}=3$ for normal hearts and $\mathrm{n}=12$ for LVNC hearts, ${ }^{* *} \mathrm{p}<0.01$ ). (D) RTqPCR data showing the increased mRNA levels of CMYA1 and reduced mRNA levels of Cx43 and Cx40 (n=3 for normal hearts and $n=12$ for LVNC hearts, ${ }^{* *} \mathrm{p}<0.01$ ).

\section{Expression and localization of CMYA1, $C_{X} 43$ and $C_{x} 40$}

To investigate the relationship between the CMYA1 protein and the identified connexins (Cx43 and Cx40), we performed immunocytochemistry, western blot analysis and RT-qPCR in the human cardiac tissues and HL1 cells. $\mathrm{Cx} 43$ and $\mathrm{Cx} 40$ were localized to the cytoplasm and membranes in the cardiac tissues and HL1 cells (Fig. 2A and Fig. 3A). Localization of the 
Fig. 3. The effect of CMYA1 on $\mathrm{Cx} 43$ and Cx40 expression in HL1 cells. (A) Representative images of $\mathrm{Cx} 43$ and $\mathrm{Cx} 40$ protein expression in HL1 cells transfected with plent6v5CMYA1 or shRNA-CMYA1, as determined by immunocytochemistry with an anti-Cx43 antibody and an anti-Cx40 antibody. The brown spots represent the $\mathrm{Cx} 43$ and $\mathrm{Cx} 40$

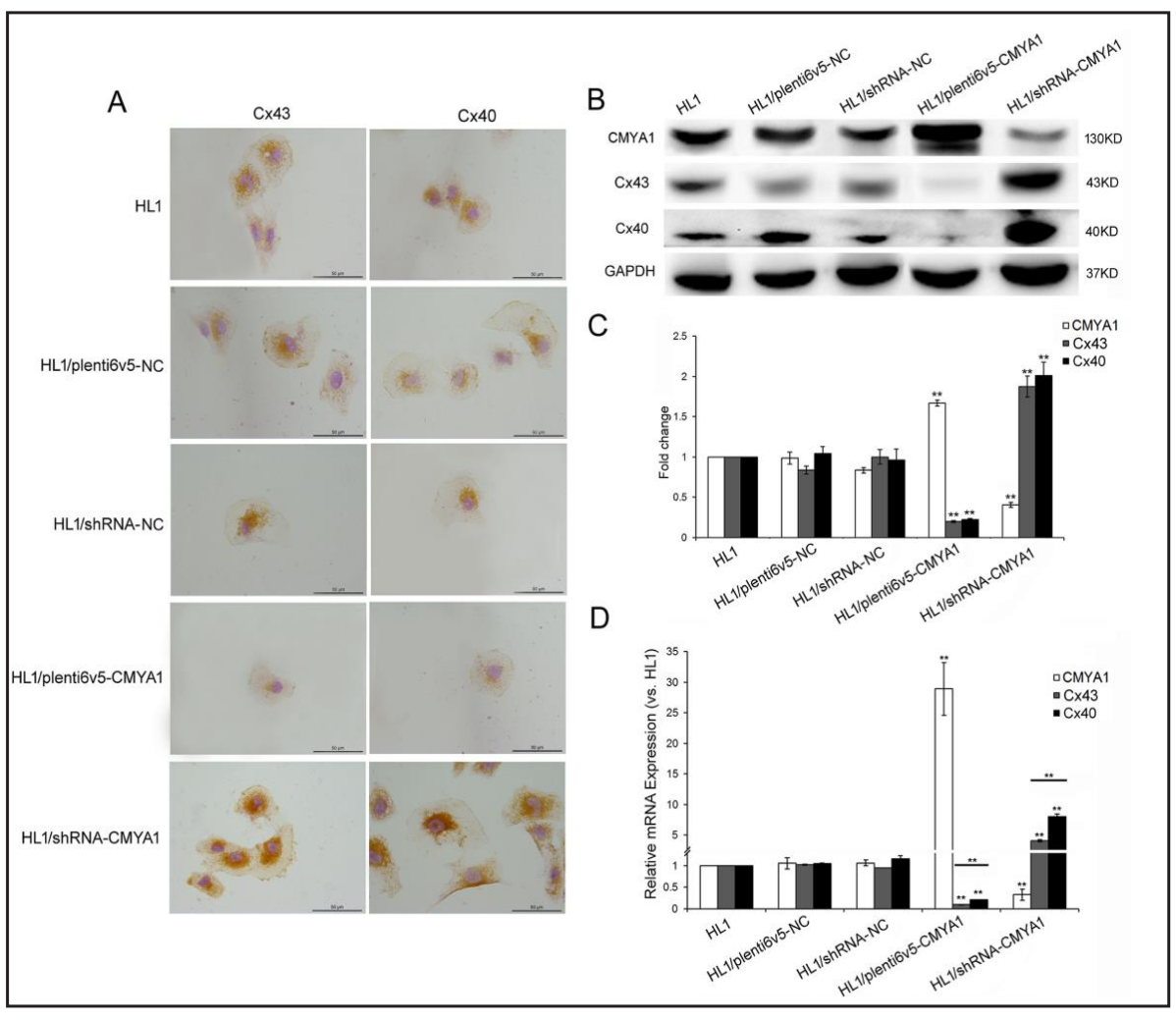
protein that lo-

calized to the cytoplasm and membrane of HL1 cells. The slides were counterstained with hematoxylin (blue-purple) (magnification 630×). (B) Western blotting was used to determine the expression of CMYA1, Cx43 and Cx40 in HL1 cells transfected with plent6v5-CMYA1 or shRNA-CMYA1 and control cells. (C) Bar graphs showing densitometric analysis of the $130 \mathrm{kDa}$ CMYA1 protein, the $43 \mathrm{kDa} \mathrm{Cx} 43$ protein and the 40 $\mathrm{kDa}$ Cx40 protein normalized to the density of the $37 \mathrm{kDa}$ GAPDH band from (B). The relative expression of each band=the density of each band/density of the GAPDH band ( $n=3$ for each group, ${ }^{* *} p<0.01$ ). (D) RTqPCR was used to determine the mRNA levels of all the above mentioned cells ( $n=3$ for each group, ${ }^{*} p<0.05$, $* * \mathrm{p}<0.01)$.

CMYA1, $\mathrm{Cx} 43$ and $\mathrm{Cx} 40$ proteins in the human cardiac tissues is indicated by arrows. CMYA1, $\mathrm{Cx} 43$ and $\mathrm{Cx} 40$ protein expression was concentrated at the ICDs of normal cardiomyocytes and at the disordered ICDs of diseased cardiomyocytes (Fig. 2A). Western blot analysis confirmed the increased cardiac CMYA1 abundance and decreased cardiac connexin abundance in the left ventricular myocardial tissues of patients with LVNC compared with their abundance in normal control heart tissues. $\mathrm{Cx} 43$ protein expression was higher than that of $\mathrm{Cx} 40$ in the ventricular myocardium (Fig. 2B). The expression of $\mathrm{Cx} 43$ and $\mathrm{Cx} 40$ in the HL1 cells in which CMYA1 was over-expressed was consistent with the results in the left ventricular myocardial tissues of patients with LVNC. Compared with that in the control group, $\mathrm{Cx} 43$ and $\mathrm{Cx} 40$ expression was increased in the HL1 cells in which CMYA1 expression was low (Fig. 3B).

\section{The interaction of CMYA1 with CX43}

Immunofluorescence revealed a strict colocalization of CMYA1 with Cx43 at the ICDs in the myocardial tissues (Fig. 4A). The ICD structures showed a disordered morphology in the human hearts with LVNC, suggesting that CMYA1 and Cx43 may have a functional relationship. To verify the protein interactions of CMYA1 and Cx43 in HL1 cells, we observed HL1 cells co-transfected with plent6v5-CMYA1 and pDsRed1-N1-Cx43 with a confocal laser 


\section{Cellular Physiology Cell Physiol Biochem 2017;44:828-842 \begin{tabular}{l|l|l} 
DOI: 10.1159/000485348 & O 2017 The Author(s). Published by S. Karger AG, Basel \\
wwww.karger.com/cpb
\end{tabular}

Fig. 4. Binding of CMYA1 and Cx43. (A) Colocalization of CMYA1 and Cx43 in human hearts. Confocal laser scanning microscope images of fluorescent double-immunohistochemical staining of CMYA1 (green) and Cx43 (red) proteins in human hearts with LVNC and normal hearts ( $m$ a g n if ic ation 400×). CMYA1 and Cx43 colocalized at the ICDs of human hearts (yellow). The nuclei were stained by DAPI (blue). (B, C) HL1 cells were co-transfected with plent6v5-C MYA1 (with EGFP and

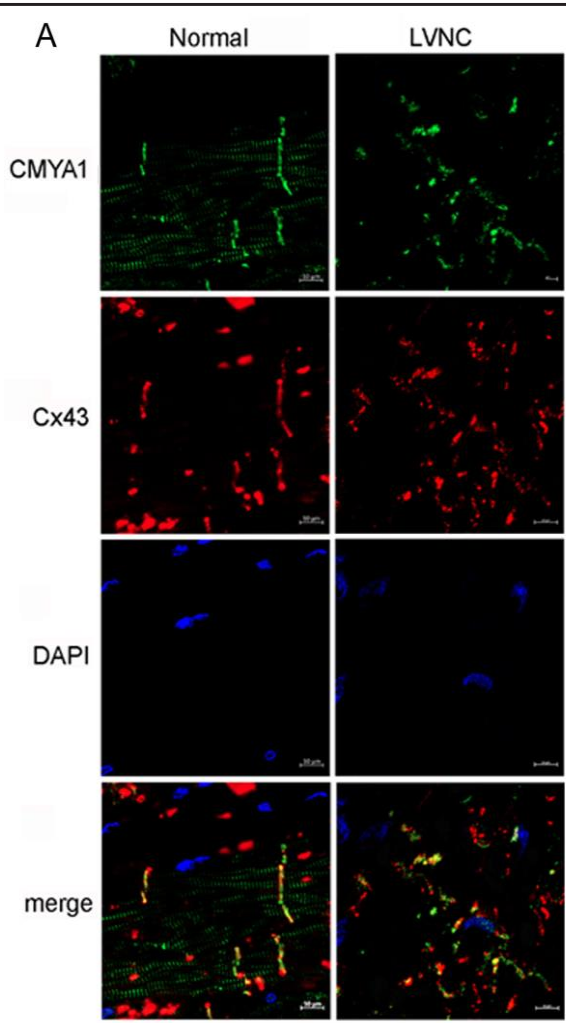

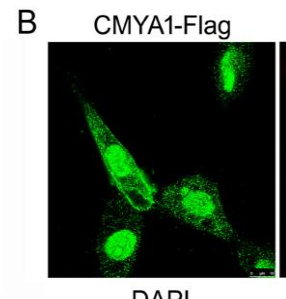
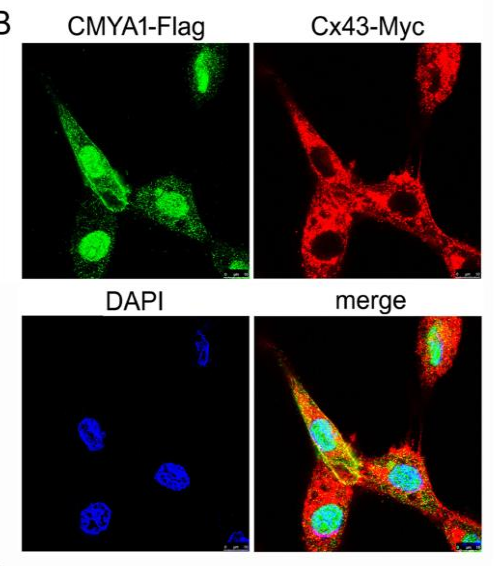

C

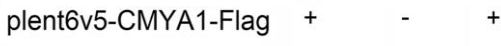
pDsRed1-N1-Cx43-Myc - + +

IP:Myc IB:Flag IP:Myc IB:Myc IP:Flag IB:Flag IP:Flag IB:Myc Input IB:Flag Input IB:Myc

FLAG tag) and pDsRed1-N1-CX43 (with DsRed1 and Myc tag) alone or in combination. (B) EGFP is visualized in green, DsRed1 is visualized in red, and colocalization at the membranes is visualized in yellow. The nuclei were stained with DAPI (blue) (magnification 630×). (C) Extracted proteins from all the above mentioned cells were untreated (input) or precipitated by an anti-FLAG or a Myc antibody and then separated by $4-12 \%$ SDS-PAGE. The transferred membrane was immunoblotted with an anti-FLAG or an Myc antibody. Co-immunoprecipitation (Co-IP) of the cell lysates showing CMYA1 binding with Cx43.

scanning microscope. The CMYA1 protein (green) colocalized with $\mathrm{Cx} 43$ (red) at the cell membranes, and the merged images are shown in yellow (Fig. 4B).

The co-immunoprecipitation assay was performed to assess the protein interactions between CMYA1 and Cx43. Two plasmids, plent6v5-CMYA1-FLAG and pDsRed1-N1CX43-Myc, were co-transfected into HL1 cells (Fig. 4C, lane 3). The cell lysates were immunoprecipitated with anti-Myc (for $\mathrm{Cx} 43$ ), and the immunoprecipitants were revealed with an anti-FLAG antibody (for CMYA1) (Fig. 4C, line 2). Conversely, the cell lysates were immunoprecipitated with anti-FLAG (for CMYA1), and the immunoprecipitants were revealed with an anti-Myc antibody (for $\mathrm{Cx} 43$ ) (Fig. 4C, line 4). The input lane showed that both CMYA1 and Cx43 were expressed after cell transfection (Fig. 4C, line 5 and 6). These results indicate that CMYA1 co-immunoprecipitates with Cx43 in HL1 cells.

\section{Function of GJIC}

To investigate $\mathrm{Cx} 43$ expression and GJIC in HL1 cells in which CMYA1 was over-expressed or knocked down, scalpel loading-dye transfer (SL-DT) and immunofluorescence assays were used. Lucifer yellow (LY) and Cx43 were observed in fewer diffusely fluorescent HL1 cells in which CMYA1 was over-expressed and in more diffusely fluorescent HL1 cells in which CMYA1 was knocked down (Fig. 5). At the same time, we also tested the phosphorylation level of $\mathrm{Cx} 43$ in the myocardial tissues and HL1 cells and determined the ratio between 


\section{Cellular Physiology and Biochemistry \begin{tabular}{l|l} 
DOI: 10.1159/000485348 & $\begin{array}{l}\text { C } 2017 \text { The Author(s). Published by S. Karger AG, Basel } \\
\text { www.karger.com/cpb }\end{array}$
\end{tabular}

Fig. 5. The effect of CMYA1 on GJIC in HL1 cells. (A) HL1 cells were transfected with plent6v5-CMYA1 or shRNA-CMYA1 and control vectors, followed by Lucifer yellow (LY) scrape loading-dye transfer assays and fluorescent immunohistochemical staining of Cx43 (magnification 200x). Scalpel cuts through the cell monolayers, leading to cell wounding and dye uptake, are depicted by dashed lines. (B) Quantitative analyses of the diffusion distance of Lucifer Yellow and the fluorescence in-

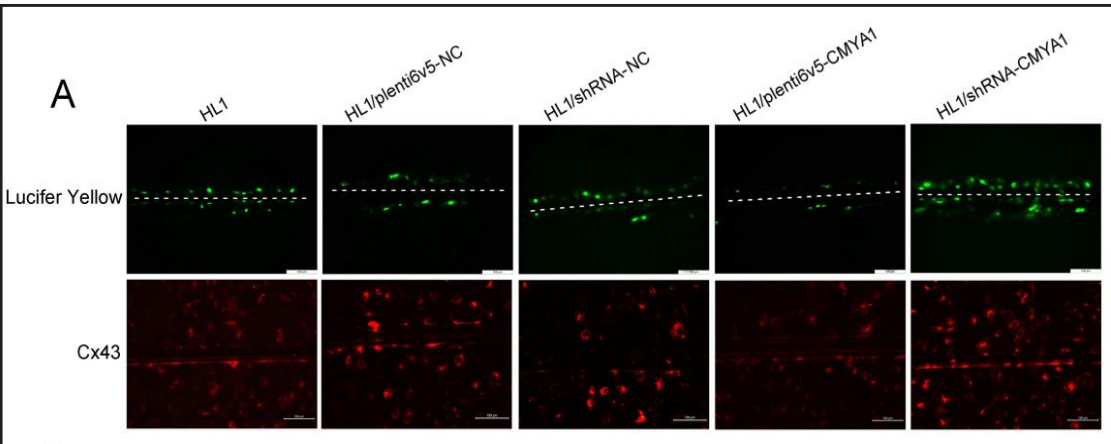

B
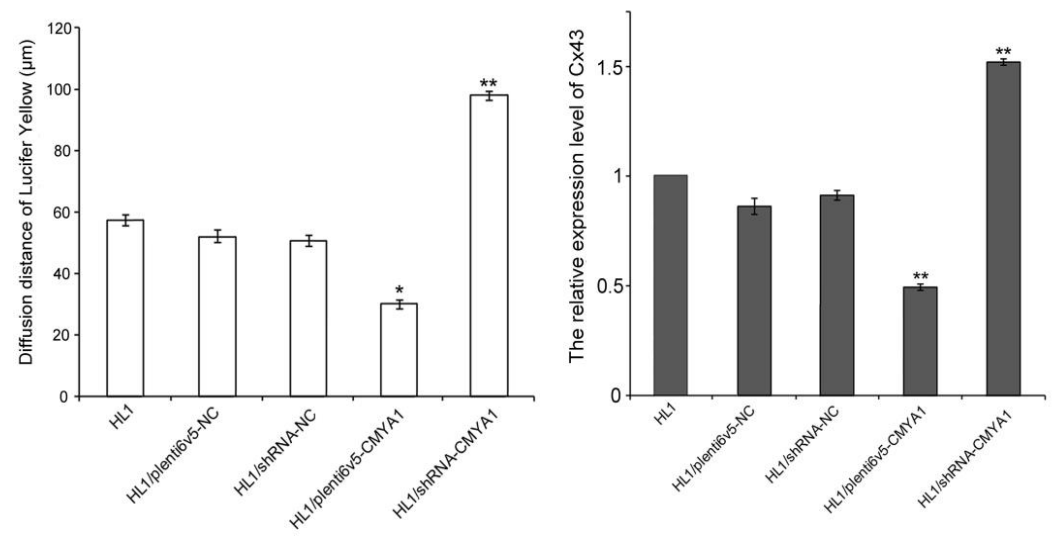
tensity of $\mathrm{Cx} 43$, representative of the GJIC efficiency and the Cx43 expression level $\left(\mathrm{n}=3\right.$ for each group, $\left.{ }^{*} \mathrm{p}<0.05,{ }^{* *} \mathrm{p}<0.01\right)$.

phosphorylated $\mathrm{Cx} 43$ and total $\mathrm{Cx} 43$ using immunoblots. The phosphorylation levels of $\mathrm{Cx} 43$ were significantly increased in the left ventricular myocardial tissues of patients with LVNC and in the HL1 cells in which CMYA1 was over-expressed (Fig. 6A, 6C). The phosphorylation levels of Cx43 were significantly decreased in the HL1 cells in which CMYA1 was knocked down (Fig. 6C).

\section{PKC signaling pathway activation is responsible for Cx43 phosphorylation}

When treated with GF109203X, HL1 cells showed an increased diffusion distance of Lucifer Yellow, enhancing the permeability of the GJ channel. When treated with PMA, HL1 cells showed a reduced diffusion distance of Lucifer Yellow, weakening the permeability of the GJ channel (Fig. 7). These results indicate that gap junction function is related to $\mathrm{Cx} 43$ phosphorylation. The expression levels of $\mathrm{PKC} \alpha$ and $\mathrm{P}-\mathrm{Cx} 43$ (S368) were significantly increased, and the expression level of Cx43 was significantly decreased in HL1 cells in which CMYA1 was over-expressed (Fig. 8). These results indicate that abnormal CMYA1 expression affects the expression and phosphorylation of $\mathrm{Cx} 43$ via the PKC signaling pathway, which is involved in the regulation of GJIC.

\section{Discussion}

To clarify the relationship between CMYA1 and LVNC pathogenesis, we studied the function of CMYA1 in human myocardial tissues and HL1 cells. In this study, we explored the expression and localization of CMYA1 and gap junction proteins, the interaction of CMYA1 with Cx43 and the effect of CMYA1 on the phosphorylation of Cx43 and the function of GJIC in cardiomyocytes.

\section{KARGER}




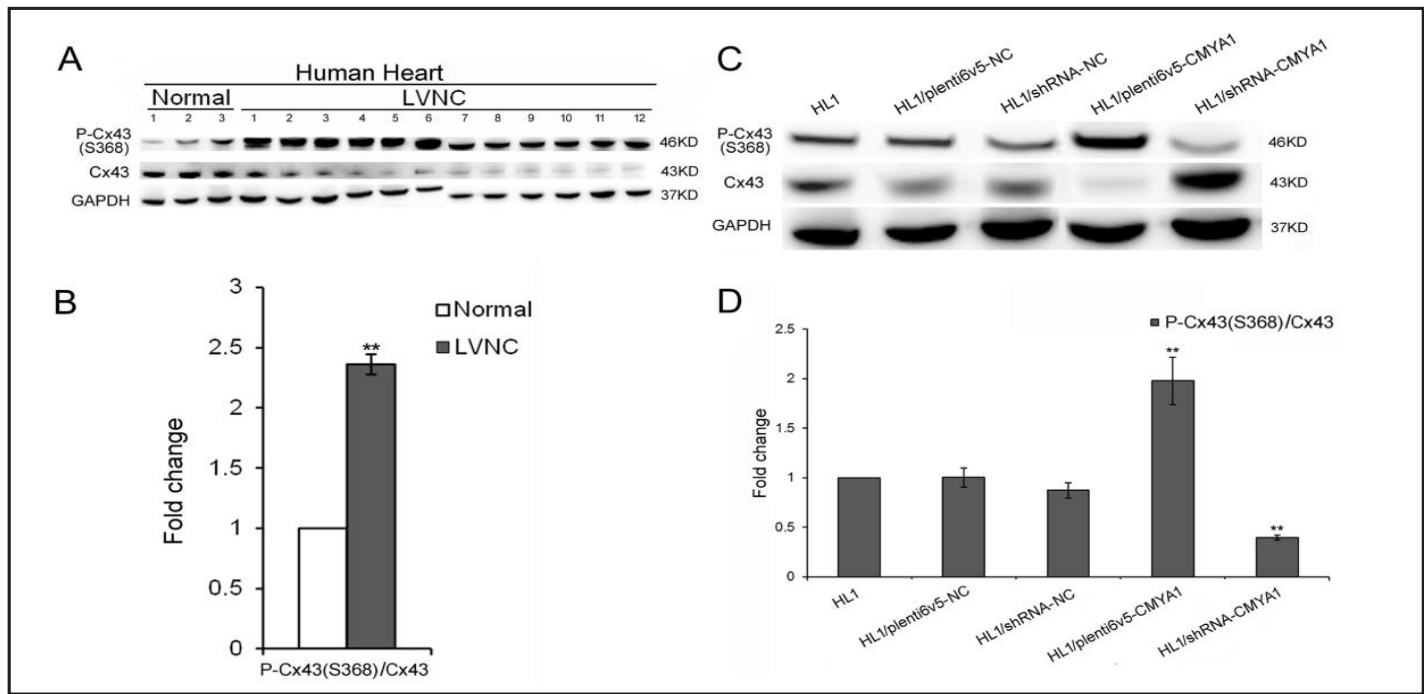

Fig. 6. The effect of CMYA1 on p-Cx43 (S368). (A) Western blot showing the increased phosphorylation levels of Cx43 (S368) in the normal human hearts and human hearts with LVNC. (B) Bar graphs showing the ratio of $\mathrm{p}-\mathrm{Cx} 43$ (S368)/Cx43 in the human hearts with LVNC ( $\mathrm{n}=3$ for normal hearts and $\mathrm{n}=12$ for LVNC hearts, ${ }^{* *} \mathrm{p}<0.01$ ). (C) Western blot analysis of $\mathrm{p}-\mathrm{Cx} 43$ (S368) in HL1 cells in which CMYA1 was over-expressed (HL1/plent6v5-CMYA1) or knocked down (HL1/shRNA-CMYA1) and control cells. GAPDH served as the quantity control. (D) Bar graphs showing the ratio of $\mathrm{p}-\mathrm{Cx} 43(\mathrm{~S} 368) / \mathrm{Cx} 43$ ( $\mathrm{n}=3$ for each group, $\left.{ }^{* *} \mathrm{p}<0.01\right)$.

Fig. 7. Modulation of GJIC by CMYA1 through the PKC signaling pathway in HL1 cells. (A) HL1 cells in which CMYA1 was over-expressed or knocked down and control cells were cultured with treatment with 30 nM GF109203X for $48 \mathrm{~h}$, $100 \mathrm{nM}$ PMA for $0.5 \mathrm{~h}$, or without any treatment (magnification 200x). Scalpel cuts through the cell monolayers leading to cell wounding and dye uptake are depicted by dashed lines. Intercellular communication was determined by measuring the diffusion distance of Lucifer Yellow. (B) Quantitative analyses of the diffusion distance of Lucifer Yellow, representative of GJIC efficiency $(n=3$ for each group, ${ }^{*} \mathrm{p}<0.05$, ** $\mathrm{p}<0.01$ ).

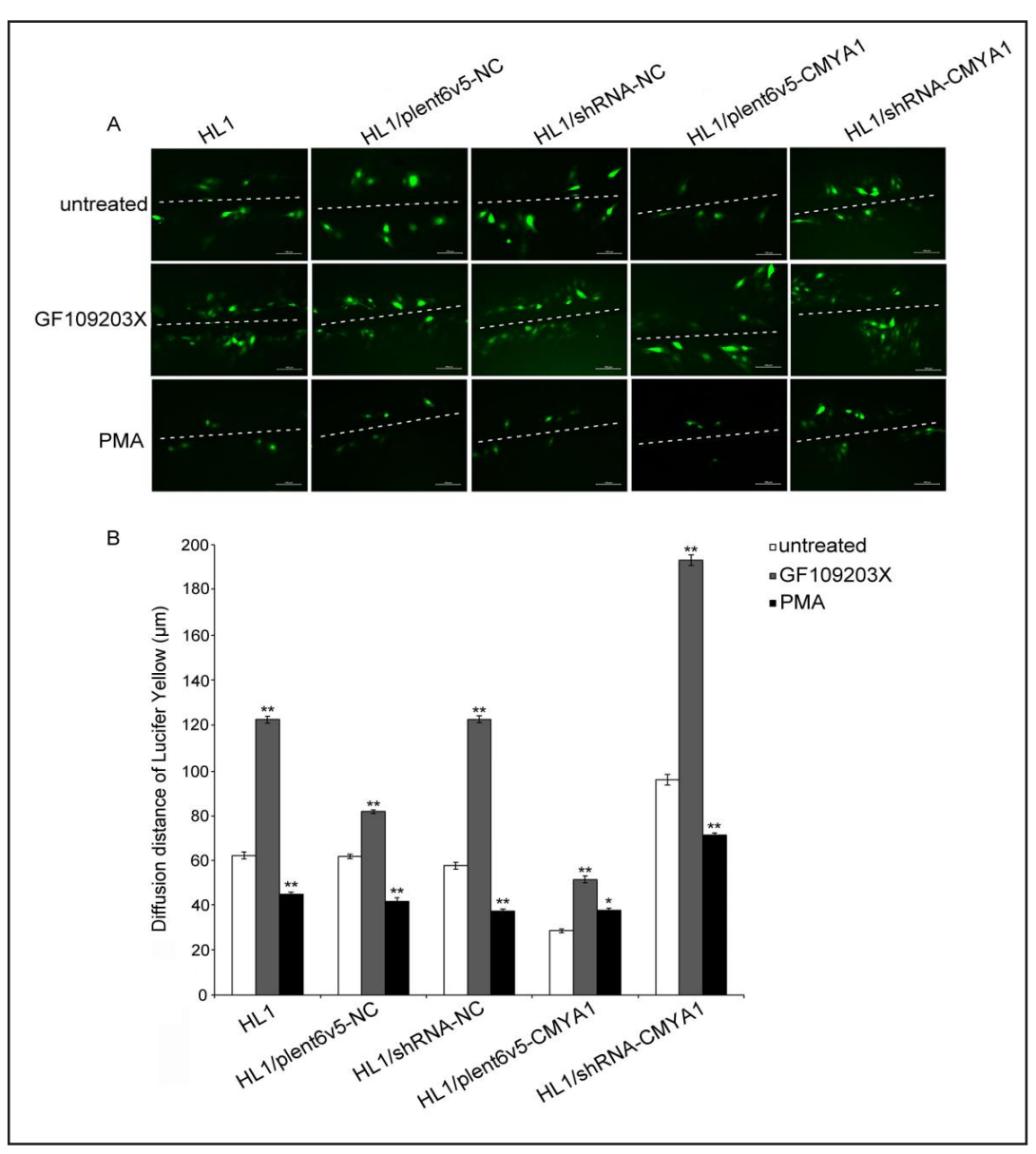


Fig. 8. The effect of activation and inhibition of the PKC signaling pathway on p-Cx43 (S368) in HL1 cells. (A) Western blotting was used to determine the expression of CMYA1, PKC $\alpha, \mathrm{Cx} 43$ and the phosphorylation of Cx43 (S368) in HL1 cells in which CMYA1 was over-expressed or knocked down and control cells with or without treatment. (B) Bar graphs showing the densitometric analysis of CMYA1, PKC $\alpha, \quad \mathrm{Cx} 43$ and p-Cx43 (S368) $\left(\mathrm{n}=3\right.$ for each group, ${ }^{* *}$ $\mathrm{p}<0.01$ ).

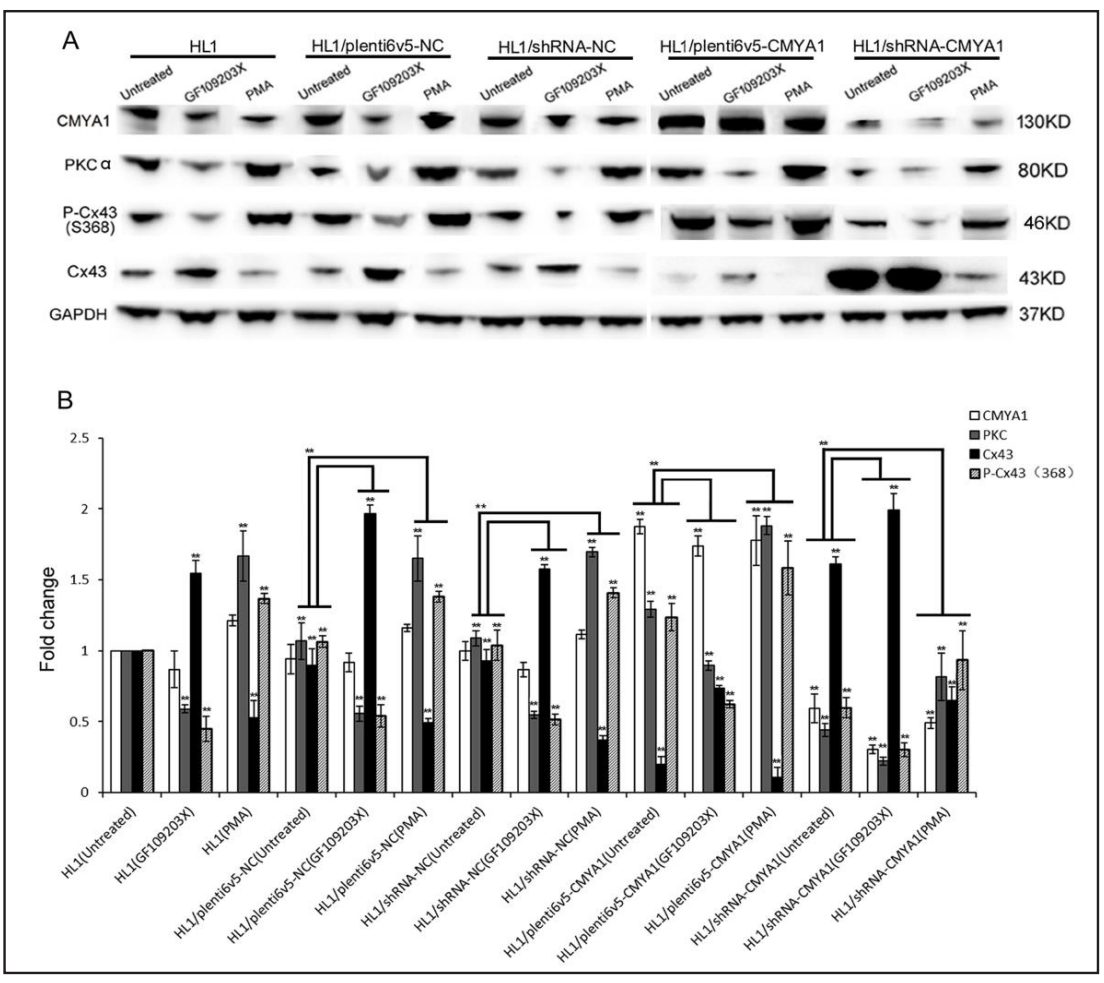

Fig. 9. Scheme of CMYA1 participating in LVNC pathogenesis via the PKC signaling pathway. CMYA1 over-expression affects the expression and phosphorylation of $\mathrm{Cx} 43$ via the PKC signaling pathway, which is involved in the regulation of GJIC. CMYA1 participates in the molecular mechanism of LVNC pathogenesis.

In this study, we monitored the differential expression of a panel of 84 genes known to be associated with gap junctions. According to the distribution and function of the genes, two genes associated with cardiomyopathy were screened out, $\mathrm{Cx} 43$ and $\mathrm{Cx} 40$. We demonstrated that abnormal CMYA1 expression can

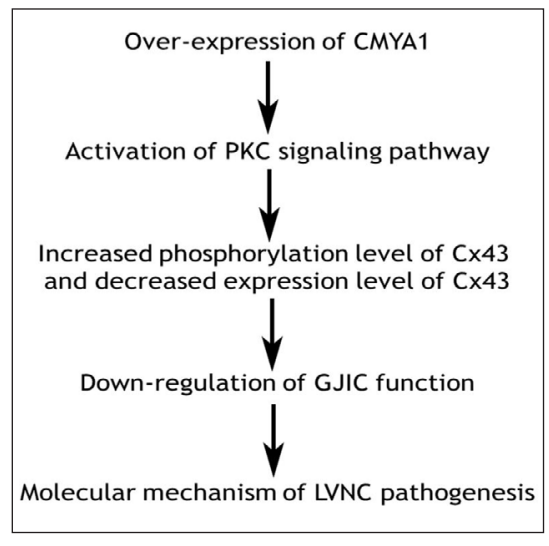
cause abnormal $\mathrm{Cx} 40$ and $\mathrm{Cx} 43$ expression at the mRNA and protein levels in HL1 cells. We also observed the increased expression and disordered distribution of CMYA1 at the ICDs and decreased expression of Cx40 and Cx43 in the LVNC myocardial tissues, potentially revealing the key role of CMYA1 in the association between connexin expression and LVNC pathogenesis. CMYA1 over-expression can lead to decreased Cx43 expression and influence its transport, localization and structure, which may result in decreased GJIC in HL1 cells. This results in adjacent cells being unable to communicate information or regulate cell growth and proliferation, leading to cell lesions [23]. We found that CMYA1 and Cx43 are co-expressed in myocardial cells, suggesting that CMYA1 may be involved in the functional regulation of gap junctions. Cx43 is the most important connexin in ventricular myocytes [24], and it is synthesized on the reticulum and transferred to the Golgi apparatus, finally aggregating to form GJs on cell membranes [25]. In a study on Cx43 gene-deficient mice, when the expression of ventricular $\mathrm{Cx} 43$ was reduced by $50 \%$, the conduction velocity of the ventricle was reduced by $38 \%$, indicating that $\mathrm{Cx} 43$ plays a decisive role in the conduction velocity of the ventricle [26]. Changes in the structure and function of gap junctions can cause arrhythmia [27-30]. The incidence of arrhythmias in 
patients with LVNC is very high. The common types of arrhythmias in patients with LVNC are ventricular arrhythmias, bundle branch blockage, atrioventricular blockage, and atrial fibrillation. The mechanism of arrhythmia in patients with LVNC may be related to the irregular branches and connections of the muscle bundle. Decreased conduction velocity and conduction blockage are important causes of arrhythmia, which can be caused by the abnormal excitability of cardiomyocytes or by the disordered electrical coupling function of the GJ channel. By studying the effects of membrane currents and GJ channels on the velocity of ventricular tachycardia, a reduction in the number of GJ channels could result in a slower myocardium conduction velocity and decreased cell membrane excitability. A reduced number of $\mathrm{GJ}$ channels can result in the excitability of various regions of the heart being nonuniform, resulting in conduction blockage [31].

GJIC, a common mode of communication between adjacent cells, is involved in cell intercellular exchange and electrical signal transmission. Gap junction-mediated intercellular communication has been recognized in cells from different tissues of various organisms and has been implicated in a variety of cellular functions and dysfunctions. A variety of factors, such as $\mathrm{pH}, \mathrm{Ca} 2+$ concentration, voltage, and cyclic nucleotides, can affect the permeability of GJ channels, mostly by changing the phosphorylation levels of GJ proteins. Some studies have shown that changes in the function of GJ channels are not consistent with changes in these factors $[32,33]$. In other words, the important factors regulating GJ channels may still be unknown. Protein-protein interaction is an important basis for many cellular functions. Signal transduction, cell cycle regulation, RNA transcription, DNA replication, and protein translation are all dependent on protein-protein interactions. Identifying which proteins have direct or indirect interaction with GJs is an important way to adequately elucidate GJ function and regulation. Immunoprecipitation experiments showed that CMYA1 binds to Cx43 in HL1 cells. The SL-DT assays showed that the function of GJIC was significantly decreased in the HL1 cells in which CMYA1 was over-expressed and significantly improved in HL1 cells in which CMYA1 was expressed at low levels. According to the immunofluorescence results in HL1 cells, Cx43 expression was weaker in HL1 cells in which CMYA1 was over-expressed and stronger in HL1 cells in which CMYA1 was expressed at low levels. These findings suggest that CMYA1 interacts with $\mathrm{Cx} 43$ and promotes the phosphorylation of $\mathrm{Cx} 43$, leading to $\mathrm{GJ}$ channel closure. Phosphorylation affects almost the entire life cycle of connexins, from synthesis, assembly, and function to degradation. The phosphorylation level of $\mathrm{Cx} 43$ is the most important factor affecting the permeability and function of GJ channels [34].

Studies have shown that multiple residues in the carboxyl-terminal region of $\mathrm{Cx} 43$ in the myocardium can be phosphorylated. Phosphorylation of Cx43 at the S368 site in the myocardium is involved in the regulation of gap junction permeability, which is dependent on phosphorylation of the PKC signaling pathway. In the myocardium, phosphorylation of Cx43 (S368) is stimulated by PMA and is indispensable for the reduction of gap junctions. In contrast, when treated with PKC inhibitors, the phosphorylation of Cx43 (S368) decreased, and the permeability of the gap junction channel was enhanced. The phosphorylation of $\mathrm{Cx} 43$ (S368) caused by the PKC signaling pathway in the myocardium leads to a conformational change in the protein, which can decrease the permeability of the gap junction channel [35]. Activation of the PKC signaling pathway resulted in high levels of $\mathrm{Cx} 43$ phosphorylation at the Ser368 site, decreased permeability of the GJ channel, and reduced GJ function [36]. We found that the phosphorylation level of Cx43 (S368) was significantly increased in LVNC tissues and HL1 cells in which CMYA1 was over-expressed. LY transmission occurred within minutes after loading in communication-competent cells, indicating the communication phenomenon of gap junctions [37]. According to the SL-DT assay results, the PKC inhibitor GF109203X and the PKC activator PMA can effectively inhibit or activate the phosphorylation of Cx43 (S368), destroying and inhibiting the structure and function of GJIC [38, 39]. This indicates that CMYA1 is involved in the PKC signaling pathway, which may regulate the phosphorylation and expression of $\mathrm{Cx} 43$.

We acknowledge that there are several limitations in this study. First, because human myocardial samples are very valuable, the number of tissue samples was small. Second, due 


\section{Cellular Physiology Cell Physiol Biochem 2017;44:828-842

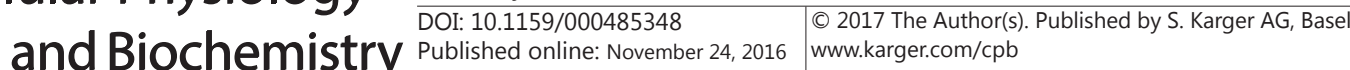 \\ Xie et al.: Effects of CMYA1 On Cx43 via the PKC Signaling Pathway}

to the progress of the test, the PKC signaling pathway was not discussed in depth. Thus, more research is needed to confirm our findings. In conclusion, our findings in human myocardial tissues and HL1 cells have indicated that abnormal CMYA1 expression affects the phosphorylation of $\mathrm{Cx} 43$ through the PKC signaling pathway, which is involved in the regulation of GJIC. Fig. 9 depicts a model for the CMYA1 molecular mechanism underlying LVNC via the PKC signaling pathway. CMYA1 participates in the molecular mechanism of LVNC pathogenesis.

\section{Abbreviations}

CMYA1 (Cardiomyopathy-associated gene 1); Cx43 (Connexin 43); CT (Cycle threshold); DAB (3, 3'-Diaminobenzidine); ECL (Enhanced chemiluminescence); GJ (Gap junction); GJIC (Gap junction intercellular communication); GAPDH (Glyceraldehyde 3-phosphate dehydrogenase); ICD (Intercalated disc); LVNC (Left ventricular noncompaction cardiomyopathy); LY (Lucifer yellow); PKC (Protein kinase C); PMA (Phorbol 12-myristate 13 acetate); PBS (Phosphate buffered saline); PCR (Polymerase Chain Reaction); SL-DT (Scalpel loading-dye transfer); TJP1 (Tight junction protein Z0-1).

\section{Acknowledgements}

Y.X. and Y.W. prepared figures and wrote the main manuscript text; Y.X. performed the experiments. All authors reviewed the manuscript.

This study was supported by CAMS Innovation Fund for Medical Sciences (No. CIFMS, 2016-I2M-1-015) and PUMC Youth Fund and the Fundamental Research Funds for the Central University (No. 33320140167).

\section{Disclosure Statement}

The authors declare that they have no competing interests.

\section{References}

1 Pardun E, Schafer S, Drenckhahn JD, Sabeh MK, Plovie ER, Caliebe A, Klopocki E, Musso G, Werdich AA, Kalwa H, Heinig M, Padera RF, Wassilew K, Bluhm J, Harnack C, Martitz J, Barton PJ, Greutmann M, Berger F, Hubner N, Siebert R, Kramer HH, Cook SA, MacRae CA, Klaassen S: Nexilin mutations are associated with left ventricular noncompaction cardiomyopathy. Mol Cell Pediatr 2015;2:1-2.

2 Captur G, Nihoyannopoulos P: Left ventricular non-compaction: genetic heterogeneity, diagnosis and clinical course. Int J Cardiol 2010;140:145-153.

-3 Arndt AK, Schafer S, Drenckhahn JD, Sabeh MK, Plovie ER, Caliebe A, Klopocki E, Musso G, Werdich AA, Kalwa H, Heinig M, Padera RF, Wassilew K, Bluhm J, Harnack C, Martitz J, Barton PJ, Greutmann M, Berger F, Hubner N, Siebert R, Kramer HH, Cook SA, MacRae CA, Klaassen S: Fine mapping of the 1p36 deletion syndrome identifies mutation of PRDM16 as a cause of cardiomyopathy. Am J Hum Genet 2013;93:67-77.

4 Hoedemaekers YM, Caliskan K, Majoor-Krakauer D, van de Laar I, Michels M, Witsenburg M, ten Cate FJ, Simoons ML, Dooijes D: Cardiac beta-myosin heavy chain defects in two families with non-compaction cardiomyopathy: linking non-compaction to hypertrophic, restrictive, and dilated cardiomyopathies. Eur Heart J 2007;28:2732-2737.

5 Klaassen S, Probst S, Oechslin E, Gerull B, Krings G, Schuler P, Greutmann M, Hurlimann D, Yegitbasi M, Pons L, Gramlich M, Drenckhahn JD, Heuser A, Berger F, Jenni R, Thierfelder L: Mutations in sarcomere protein genes in left ventricular noncompaction. Circulation 2008;117:2893-2901. 


\section{Cellular Physiology Cell Physiol Biochem 2017;44:828-842 \begin{tabular}{l|l} 
and Biochemistry Publisnea onine. November 24, 2016 & $\begin{array}{l}\text { (C) } 2017 \text { The Author(s). Published by S. Karger AG, Basel } \\
\text { www.karger.com/cpb }\end{array}$
\end{tabular}}

6 Pantazis AA, Elliott PM: Left ventricular noncompaction. Curr Opin Cardiol 2009;24:209-213.

7 Probst S, Oechslin E, Schuler P, Greutmann M, Boye P, Knirsch W, Berger F, Thierfelder L, Jenni R, Klaassen S: Sarcomere gene mutations in isolated left ventricular noncompaction cardiomyopathy do not predict clinical phenotype. Circ Cardiovasc Genet 2011;4:367-374.

-8 Fatkin D, Seidman CE, Seidman JG: Genetics and disease of ventricular muscle. Cold Spring Harb Perspect Med 2014;4:a021063.

-9 Wang DZ, Hu X, Lin JL, Kitten GT, Solursh M, Lin JJ: Differential displaying of mRNAs from the atrioventricular region of developing chicken hearts at stages 15 and 21 Front Biosci 1996;1:a1-15.

$>10$ Jung-Ching Lin J, Gustafson-Wagner EA, Sinn HW, Choi S, Jaacks SM, Wang DZ, Evans S, Li-Chun Lin J: Structure, Expression, and Function of a Novel Intercalated Disc Protein, Xin. J Med Sci 2005;25:215-222.

11 Wang DZ, Reiter RS, Lin JL, Wang Q, Williams HS, Krob SL, Schultheiss TM, Evans S, Lin JJ: Requirement of a novel gene, Xin, in cardiac morphogenesis. Development 1999;126:1281-1294.

12 Sinn HW, Balsamo J, Lilien J, Lin JJ: Localization of the novel Xin protein to the adherens junction complex in cardiac and skeletal muscle during development. Dev Dyn 2002;225:1-13.

13 Jain SK, Schuessler RB, Saffitz JE: Mechanisms of delayed electrical uncoupling induced by ischemic preconditioning. Circ Res 2003;92:1138-1144.

14 Schulz R, Gres P, Skyschally A, Duschin A, Belosjorow S, Konietzka I, Heusch G: Ischemic preconditioning preserves connexin 43 phosphorylation during sustained ischemia in pig hearts in vivo. FASEB J 2003;17:1355-1357.

15 Solan JL, Marquez-Rosado L, Sorgen PL, Thornton PJ, Gafken PR, Lampe PD: Phosphorylation at S365 is a gatekeeper event that changes the structure of $\mathrm{Cx} 43$ and prevents down-regulation by PKC. J Cell Biol 2007;179:1301-1309.

16 Wang Q, Lin JL, Erives AJ, Lin CI, Lin JJ: New insights into the roles of Xin repeat-containing proteins in cardiac development, function, and disease. Int Rev Cell Mol Biol 2014;310:89-128.

17 Goossens S, Janssens B, Bonne S, De Rycke R, Braet F, van Hengel J, van Roy F: A unique and specific interaction between alphaT-catenin and plakophilin-2 in the area composita, the mixed-type junctional structure of cardiac intercalated discs. J Cell Sci 2007;120:2126-2136.

18 Kostin S, Rieger M, Dammer S, Hein S, Richter M, Klovekorn WP, Bauer EP, Schaper J: Gap junction remodeling and altered connexin43 expression in the failing human heart. Mol Cell Biochem 2003;242:135-144.

19 Sohl G, Willecke K: Gap junctions and the connexin protein family. Cardiovasc Res 2004;62:228-232.

20 Cui C, Zhang H, Guo LN, Zhang X, Meng L, Pan X, Wei Y: Inhibitory effect of NBL1 on PDGF-BBinduced human PASMC proliferation through blockade of PDGFbeta-p38MAPK pathway. Biosci Rep 2016;36:e00374.

-21 Wang G, Liu X, Meng L, Liu S, Wang L, Li J, Cui C, Meng J, Hu S, Wei Y: Up-regulated lipocalin-2 in pulmonary hypertension involving in pulmonary artery SMC resistance to apoptosis. Int J Biol Sci 2014;10:798-806.

22 Chalfie M, Tu Y, Euskirchen G, Ward WW, Prasher DC: Green fluorescent protein as a marker for gene expression. Science 1994;263:802-805.

-23 Goldberg GS, Moreno AP, Lampe PD: Gap junctions between cells expressing connexin 43 or 32 show inverse permselectivity to adenosine and ATP. J Biol Chem 2002;277:36725-36730.

-24 Kanter HL, Saffitz JE, Beyer EC: Cardiac myocytes express multiple gap junction proteins. Circ Res 1992;70:438-444.

25 Saez JC, Berthoud VM, Branes MC, Martinez AD, Beyer EC: Plasma membrane channels formed by connexins: their regulation and functions. Physiol Rev 2003;83:1359-1400.

-26 Thomas SA, Schuessler RB, Berul CI, Beardslee MA, Beyer EC, Mendelsohn ME, Saffitz JE: Disparate effects of deficient expression of connexin43 on atrial and ventricular conduction: evidence for chamber-specific molecular determinants of conduction. Circulation 1998;97:686-691.

27 Beardslee MA, Lerner DL, Tadros PN, Laing JG, Beyer EC, Yamada KA, Kleber AG, Schuessler RB, Saffitz JE: Dephosphorylation and intracellular redistribution of ventricular connexin 43 during electrical uncoupling induced by ischemia. Circ Res 2000;87:656-662.

28 Dupont E, Ko Y, Rothery S, Coppen SR, Baghai M, Haw M, Severs NJ: The gap-junctional protein connexin40 is elevated in patients susceptible to postoperative atrial fibrillation. Circulation 2001;103:842-849. 


\section{Cellular Physiology Cell Physiol Biochem 2017;44:828-842

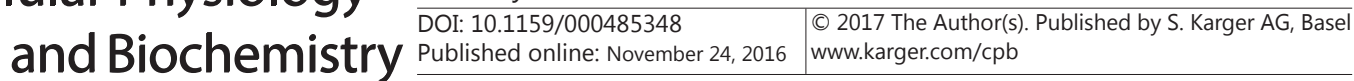 \\ Xie et al.: Effects of CMYA1 On Cx43 via the PKC Signaling Pathway}

29 Hagendorff A, Schumacher B, Kirchhoff S, Luderitz B, Willecke K: Conduction disturbances and increased atrial vulnerability in Connexin40-deficient mice analyzed by transesophageal stimulation. Circulation 1999;99:1508-1515.

-30 Kanagaratnam P, Rothery S, Patel P, Severs NJ, Peters NS: Relative expression of immunolocalized connexins 40 and 43 correlates with human atrial conduction properties. J Am Coll Cardiol 2002;39:116-123.

-31 Rudy Y, Shaw RM: Cardiac excitation: an interactive process of ion channels and gap junctions. Adv Exp Med Biol 1997;430:269-279.

-32 Herve JC, Plaisance I, Loncarek J, Duthe F, Sarrouilhe D: Is the junctional uncoupling elicited in rat ventricular myocytes by some dephosphorylation treatments due to changes in the phosphorylation status of Cx43? Eur Biophys J 2004;33:201-210.

33 Alesutan I, Voelkl J, Stockigt F, Mia S, Feger M, Primessnig U, Sopjani M, Munoz C, Borst O, Gawaz M, Pieske B, Metzler B, Heinzel F, Schrickel JW, Lang F: AMP-activated protein kinase alpha1 regulates cardiac gap junction protein connexin 43 and electrical remodeling following pressure overload. Cell Physiol Biochem 2015;35:406-418.

-34 Lampe PD, Lau AF: Regulation of gap junctions by phosphorylation of connexins. Arch Biochem Biophys 2000;384:205-215.

35 Bao X, Reuss L, Altenberg GA: Regulation of purified and reconstituted connexin 43 hemichannels by protein kinase C-mediated phosphorylation of Serine $368 \quad$ J Biol Chem 2004;279:20058-20066.

-36 Ek-Vitorin JF, King TJ, Heyman NS, Lampe PD, Burt JM: Selectivity of connexin 43 channels is regulated through protein kinase C-dependent phosphorylation. Circ Res 2006;98:1498-1505.

-37 el-Fouly MH, Trosko JE, Chang CC: Scrape-loading and dye transfer. A rapid and simple technique to study gap junctional intercellular communication. Exp Cell Res 1987;168:422-430.

-38 Lampe PD: Analyzing phorbol ester effects on gap junctional communication: a dramatic inhibition of assembly. J Cell Biol 1994;127:1895-1905.

39 Lin H, Ogawa K, Imanaga I, Tribulova N: Alterations of connexin 43 in the diabetic rat heart. Adv Cardiol 2006;42:243-254. 